\title{
The Effect of Portfolio Assessment on Learning Idioms in Writing
}

\author{
Abdorreza Tahriri \\ Department of English Language, Faculty of Literature and Humanities, University of Guilan, Rasht, Iran \\ E-mail: Atahriri@gmail.com \\ Masoud Khalili Sabet \\ Department of English Language, Faculty of Literature and Humanities, University of Guilan, Rasht, Iran \\ E-mail: Sabetma2002@yahoo.com \\ Afrouz Aeineh (Corresponding author) \\ Department of English Language, Faculty of Literature and Humanities, University of Guilan, Rasht, Iran \\ E-mail: Afrouz_Aeineh@yahoo.com
}

Received: 13-02- 2013

Accepted: 28-03-2013

doi:10.7575/aiac.ijels.v.2n.2p.53

URL: http://dx.doi.org/10.7575/aiac.ijels.v.2n.2p.53

Published: $30-04-2014$

\begin{abstract}
The present study sought to investigate the effect of portfolio assessment on idiom competence of Iranian EFL learners. For the purpose of this study, 30 students from upper-intermediate level of English proficiency took part in this study. They were chosen through convenience sampling from a language institute in Rasht, Iran. They were randomly divided into experimental and control groups. A TOEFL test and a test of idioms were given to the students to ensure their homogeneity in terms of language proficiency and knowledge of idioms, respectively. The experimental group was intended to create a portfolio and put their writing samples, in which idioms were used, in the portfolio. They were involved in the process of self-and-peer assessment. The teacher also provided them with feedback and comments. However, the control group received a kind of traditional instruction. In other words, the control group used the idioms in their writing without receiving any comments and delivered it to their teacher to be scored. The treatment lasted for 10 sessions and a post-test was administered in the end. Independent samples t-tests were used to analyze the data gathered from the pretests and the posttest. The findings indicated that there was a statistically significant difference between the two groups in terms of idioms and portfolio was found to be able to improve students' knowledge of idioms. The results of this study have some implications for teaching and learning idioms.
\end{abstract}

Keywords: portfolio assessment, idiom, EFL, self-and-peer assessment

\section{Introduction}

Writing is one way of communication which is very important in the modern world, whether it takes the form of paperand-pencil writing or email. Writing is an interactive process between the writer and the reader. The imposed demand of writing on the text is much more than that of the spoken interaction, since there is no immediate feedback as a guide in written interaction (Olshtain, 2001).

Expressing one's ideas coherently and accurately in writing is a major achievement which even native speakers hardly can do (Celce-Murcia, 2001). Effective writing requires knowledge of grammar, words, collocations, idioms and expressions, etc. The English language contains thousands of idioms. Since idioms are the use of language in a way that is not literal, they are harder to produce and understand especially for EFL learners. Students may write well and produce grammatically correct sentences but they seldom use idioms because they don't know most of the idioms or they don't know where and how to use them in their writing. One way to tackle this problem may be keeping portfolio. According to Hornby (2006), portfolio is "a collection of photographs, drawings, etc. that you use as an example of your work, especially when applying for a job (P. 1172)." Richards and Schmidt (2002) defined portfolio as a purposeful collection of artifacts that gives some information about someone's effort, progress and achievement. It can be used as a learning or assessment tool. Portfolio has some characteristics as follows:

1. The learner can decide what to put in the portfolio;

2. After receiving feedback and comments from the teacher or peers, learners can revise materials in the portfolio;

3. Since the learners assess and reflect on the work in the portfolio, they can be aware of their progress and personal development;

4. There is evidence of mastery of knowledge;

5. Artifacts can take many forms such as written work, audio recording, video recording, etc. 
According to Gipps (1994), performance assessment is different from authentic assessment. Performance assessment that is done in an authentic context is called authentic assessment. It means that it is produced in the classroom as a normal work not for assessment. We cannot consider all performance assessments as authentic. It is true to say that a special case of performance assessment is authentic assessment. Portfolio is a kind of authentic assessment since it includes samples of actual student performance. In portfolio best samples of students' performance are elicited under normal conditions in the classroom environment.

By documenting their learning and archiving materials, students can have a collection of their sample work in order to see their improvement over time. By this way students can have a greater control and ownership of their learning and teachers can evaluate students' performance easily. Thus, using portfolio, as a kind of alternative assessment, may help students to overcome their problems in writing and may enhance their learning in a period of time.

Most of the studies reported the positive effects of portfolio on improving writing ability and some of them examined specifically its effect on vocabulary improvement of the learners. Among them Berimani and Mohammadi (2013) investigated the effect of portfolio assessment on vocabulary learning of Iranian intermediate EFL learners. The results showed that portfolio group gained better scores. So they concluded that using portfolio as an alternative assessment improves learners' vocabulary learning. In another study done by Khodashenas, Kishani Farahani and Amouzegar (2013), the effect of portfolio keeping on the improvement of advanced EFL learners' writing ability was explored. The findings revealed that the portfolio assessment had a positive effect on learners' overall writing and their achievement in terms of focus, elaboration, organization and vocabulary. In a study conducted by Ghoorchaei, Tavakoli and Nejad Ansari (2010), the effect of portfolio assessment on essay writing was investigated. The researchers conducted semistructured interviews in order to find out students' views about portfolio assessment. Four students with higher writing scores and four students with lower writing scores were selected to participate in the interview. By analyzing transcription of the interviews, three different themes were identified, namely writing achievement, use of reflection and awareness of writing. The results of quantitative data analysis revealed that portfolio assessment had a positive effect on the participants' achievement in their overall writing ability as well as their achievement in sub-skills of focus, elaboration, organization and vocabulary.

Although most of the previous studies investigated the effect of portfolio on the improvement of overall writing ability, the present study seeks to investigate the impact of portfolio as an alternative assessment specifically on learning idioms and expressions. Few studies, if any have dealt with this issue so far.

\section{Research Question}

The present study aims to answer the following question:

Can portfolio assessment enhance EFL learners' knowledge of idiom knowledge at upper-intermediate level?

\section{Research hypothesis}

Regarding the above mentioned research question, the following hypothesis was put forward:

H0: There is no difference between idiom competence of EFL learners who use portfolio assessment and students who do not.

\section{Methodology}

The design of this study was quasi experimental in nature since the two groups were randomly divided into two groups of experimental and control and the groups were naturally assembled as intact classes.

\subsection{Participants}

The participants of this study were 30 EFL students at upper-intermediate level in Rasht. The students of control and experimental groups were both males and females. Their age range was between 18- 32. They were assigned to two groups: Experimental group $(\mathrm{N}=15)$ and control group $(\mathrm{N}=15)$.

\subsection{Instruments}

To check the students' homogeneity regarding their language proficiency a TOEFL test was given to the students.

A pretest of idioms was administered to ensure that students were unfamiliar with the idioms. The idioms were chosen by the researchers. They were selected from Purland's (2011) book named "Talk a lot". The posttest questions were also chosen from this book.

In order to determine the effect of instructions on idiom knowledge of the students, a post test was given to both groups of participants.

\subsection{Procedure}

In this study 50 idioms were chosen to be taught to experimental and control groups. The idioms were unknown to the students as it was revealed in the pretest which was administered in the beginning of the study. Five idioms were taught to both groups each session. The students in the experimental and control groups were required to use the idioms in their writing which was assigned by the teacher. They could make the idioms bold or highlighted. The difference between the two groups was that, the experimental group kept their writing in the portfolio. The teacher commented on their writing. They also gave their writing to one of their classmates and he/she assessed their writing. Then they reflected on their work and revised their writing and put the revised version in the portfolio. However, the control group used the chosen idioms in their writing and gave their sample works to the teacher to be rated. In addition to the new 
idioms related to the current session, all of the students could use the idioms related to previous sessions in their writing.

\section{Results and Discussion}

At first, in order to examine whether there was any significant difference between the two groups in terms of overall language proficiency, an independent samples t-test was carried out on the pretest scores. Table 1 indicates descriptive statistics for the pre-test scores.

Table 1. Descriptive statistics for pre-test scores regarding language proficiency

\begin{tabular}{llccc}
\hline \multicolumn{1}{c}{ Groups } & $\mathrm{N}$ & Mean & SD & Std. Error Mean \\
\hline Control & 15 & 75.73 & 9.49 & 2.45 \\
Experimental & 15 & 77.00 & 7.88 & 2.03 \\
\hline
\end{tabular}

Table 2. Independent Samples Test (Pretest 1)

\begin{tabular}{|c|c|c|c|c|c|c|c|c|c|}
\hline & \multicolumn{2}{|c|}{$\begin{array}{l}\text { Levene's Test } \\
\text { for Equality of } \\
\text { Variances } \\
\end{array}$} & \multicolumn{7}{|c|}{ t-test for Equality of Means } \\
\hline & \multirow[t]{2}{*}{$\mathrm{F}$} & \multirow[t]{2}{*}{ Sig. } & \multirow[t]{2}{*}{$\mathrm{t}$} & \multirow[t]{2}{*}{$\mathrm{df}$} & \multirow[t]{2}{*}{$\begin{array}{l}\text { Sig. }(2- \\
\text { tailed) }\end{array}$} & \multirow[t]{2}{*}{$\begin{array}{c}\text { Mean } \\
\text { Difference }\end{array}$} & \multirow[t]{2}{*}{$\begin{array}{l}\text { Std. Error } \\
\text { Difference }\end{array}$} & \multicolumn{2}{|c|}{$\begin{array}{c}95 \% \text { Confidence Interval } \\
\text { of the Difference }\end{array}$} \\
\hline & & & & & & & & Lower & Upper \\
\hline $\begin{array}{l}\text { Equal variances } \\
\text { assumed }\end{array}$ & .129 & .722 & -.398 & 28 & .694 & -1.26667 & 3.18548 & -7.79183 & 5.25850 \\
\hline $\begin{array}{l}\text { Equal variances } \\
\text { not assumed }\end{array}$ & & & -.398 & 27.08 & .694 & -1.26667 & 3.18548 & -7.80174 & 5.26841 \\
\hline
\end{tabular}

According to table 2, which compares the results of the pretest of the two groups, we can claim that there was no significant difference between the two groups before the treatment as far as their language proficiency is concerned. In table 2, Levene's test shows that the value is .72 which is higher than .05 . Therefore the variance is assumed to be equal. With this assumption, the Sig. value is .69 which is higher than .05 . We can conclude that there is no significant difference between the means of the two groups.

Since the focus of the study was on the idiom knowledge, another pretest was given to the participating students and another independent samples t-test was administered to check the homogeneity of the groups in terms of idiom knowledge. Table 3 and 4 highlight the information of descriptive statistics and independent samples t-test respectively.

Table 3. Descriptive statistics for pre-test scores regarding idiom knowledge

\begin{tabular}{lllll}
\hline Groups & $\mathrm{N}$ & Mean & SD & Std. Error Mean \\
\hline Control & 15 & 4.13 & 1.72 & .44 \\
Experimental & 15 & 4.46 & 1.30 & .33 \\
\hline
\end{tabular}

As it can be seen in table 3, the mean of the control group and experimental groups was 4.13 and 4.46 respectively. Moreover, the standard deviation of the control group was 1.72 and the control group had a standard deviation of 1.30 . It is quite obvious that both groups were close to each other in terms of idiom knowledge.

Table 4. Independent Samples Test (pretest 2)

Levene's Test for $\quad$ t-test for Equality of Means
Equality of
Variances

\begin{tabular}{|c|c|c|c|c|c|c|c|}
\hline $\mathrm{F}$ & Sig. & $\mathrm{t}$ & $\mathrm{df}$ & $\begin{array}{l}\text { Sig. (2- } \\
\text { tailed) }\end{array}$ & $\begin{array}{c}\text { Mean } \\
\text { Difference }\end{array}$ & $\begin{array}{l}\text { Std. Error } \\
\text { Difference }\end{array}$ & $\begin{array}{l}95 \% \text { Confidence } \\
\text { Interval of the }\end{array}$ \\
\hline
\end{tabular}

\begin{tabular}{|c|c|c|c|c|c|c|c|c|c|}
\hline & & & & & & & & \multicolumn{2}{|c|}{ Difference } \\
\hline & & & & & & & & Lower & Upper \\
\hline $\begin{array}{c}\text { Equal variances } \\
\text { assumed }\end{array}$ & .807 & .377 & -.597 & 28 & .555 & -.33333 & .55834 & -1.47705 & .81038 \\
\hline $\begin{array}{l}\text { Equal variances not } \\
\text { assumed }\end{array}$ & & & -.597 & 26.032 & .556 & -.33333 & .55834 & -1.48095 & .81429 \\
\hline
\end{tabular}


According to table 4 , the $\mathrm{p}$ value is .55 which is higher than .05 . Therefore, it can be concluded that there was no significant difference in terms of idiom competence of the two groups.

Then in order to answer the research question which dealt with the effect of portfolio assessment on improving EFL learners' idiom knowledge at upper-intermediate level, another independent samples T-test was used.

Table 5. Descriptive statistics for posttest scores

\begin{tabular}{lllll}
\hline Groups & $\mathrm{N}$ & Mean & $\mathrm{SD}$ & Std. Error Mean \\
\hline Control & 15 & 38.46 & 4.76 & 1.23 \\
Experimental & 15 & 25.06 & 4.57 & 1.18 \\
\hline
\end{tabular}

Table 6. Independent Samples Test (posttest)

\begin{tabular}{|c|c|c|c|c|c|c|c|c|c|}
\hline & \multicolumn{2}{|c|}{$\begin{array}{l}\text { Levene's Test } \\
\text { for Equality of } \\
\text { Variances }\end{array}$} & \multicolumn{7}{|c|}{ t-test for Equality of Means } \\
\hline & \multirow[t]{2}{*}{$\mathrm{F}$} & \multirow[t]{2}{*}{ Sig. } & \multirow[t]{2}{*}{$\mathrm{t}$} & \multirow[t]{2}{*}{$\mathrm{df}$} & \multirow{2}{*}{$\begin{array}{l}\text { Sig. } \\
(2- \\
\text { tailed) }\end{array}$} & \multirow[t]{2}{*}{$\begin{array}{c}\text { Mean } \\
\text { Difference }\end{array}$} & \multirow[t]{2}{*}{$\begin{array}{l}\text { Std. Error } \\
\text { Difference }\end{array}$} & \multicolumn{2}{|c|}{$\begin{array}{l}95 \% \text { Confidence Interval } \\
\text { of the Difference }\end{array}$} \\
\hline & & & & & & & & Lower & Upper \\
\hline $\begin{array}{l}\text { Equal variances } \\
\text { assumed }\end{array}$ & .046 & .832 & 7.858 & 28 & .000 & 13.40000 & 1.70527 & 9.90692 & 16.89308 \\
\hline $\begin{array}{l}\text { Equal variances } \\
\text { not assumed }\end{array}$ & & & 7.858 & 27.954 & .000 & 13.40000 & 1.70527 & 9.90666 & 16.89334 \\
\hline
\end{tabular}

As table 6 depicts, the value sig based on Levene's test is higher than .05 which indicates that the variances are equal. Significance of t-test is .0 which is less than .05 . As a result, there is a significant difference between the means of the two groups. Hence, the null hypothesis of this study was rejected.

In table 6, the results indicate a significant difference between the performances of the two groups. Comparison of the posttest scores of the two groups leads to the rejection of the null hypothesis. This means that there is a significant difference between the two groups after implementing the treatment; thus we can claim that using portfolio had a significant effect on the students' knowledge of idioms.

Previously conducted studies are not specifically concerned with knowledge of idioms. The similarity relates to portfolio in the main. The results of this study echo earlier findings regarding the effectiveness of portfolios. It is to some extent consistent with Mohammadi and Berimani's (2013) findings that portfolio assessment improves students' vocabulary. It is also in line with Ghoorchaei, Tavakoli and Nejad Ansari's (2010) findings that portfolio empowers students' overall writing ability and sub-skills of focus, elaboration, organization and vocabulary.

\section{Conclusion}

The purpose of this study was to investigate the effectiveness of using portfolio on learning idioms and expressions. The statistically significant difference between the performances of the two groups demonstrated that portfolio keeping which consists of self assessment, peer assessment and teacher feedback helped students to learn better. The findings of this study seem to have implications for language learners and teachers. Portfolio provides opportunities for the learners to assess themselves regularly. Teachers can introduce portfolios in their classes to help students be aware of their learning process. Further research is required to examine the effectiveness of using portfolio in teaching and learning idioms in different contexts. It is hoped that the present and the coming studies be helpful in teaching and learning idioms.

\section{References}

Berimani, SH. \& Mohammadi, M. (2013). Investigating the effect of portfolio assessment on vocabulary learning of Iranian EFL learners. ELT Voices- india, 3(6), 29-39.

Celce-Murcia, M (Ed.). (2001). Teaching English as a second or foreign language. USA: Heinle \& Heinle.

Ghoorchaei, B, Tavakoli, M, \& Nejad Ansari, D. (2010). The impact of portfolio assessment on Iranian EFL students' essay writing: a process oriented approach. GEMA online journal of language studies, 10(3). 35-51.

Gipps, C. V. (1994). Beyond testing: Towards a theory of educational assessment. Washington,DC: The Falmer Press.

Hornby, A.S. (2006). Oxford advanced learner's dictionary ( $7^{\text {th }}$ ed.). Oxford: Oxford university press. 
Khodashenas, M, R., Kishani Farahani, S \& Amouzegar, E. (2013). The effect of keeping portfolios on writing ability of advanced EFL learners. International journal of language learning and applied linguistics world, 4 (2), .80-88.

Olshtain, E. (2001). Functional tasks for mastering the mechanics of writing and going just beyond. In M. Celce-Murcia (Ed.), Teaching English as a second or foreign language (p. 207). USA: Heinle \& Heinle.

Purland, M. (2011). Talk a lot: spoken English course: a great way to learn how to really speak English. UK: English banana.com.

Richards, J.C., \& Schmidt, R. (2002).Longman dictionary of language teaching \& applied linguistics ( $3^{\text {rd }}$ ed.). London: Longman (Pearson Education). 